\title{
Strategic Orientation and Business Performance in West Sumatera
}

\author{
Whyosi Septrizola
}

\author{
${ }^{1}$ Universitas Negeri Padang, Padang, Indonesia \\ ${ }^{*}$ Corresponding author. Email: whyosiseptrizola.ws@gmail.com
}

\begin{abstract}
Competition during this period of disruption was getting higher and spread to the Micro, Small, and Medium Enterprises (MSMEs) level. With good and sustainable business performance growth, this provides an opportunity for MSMEs to become large businesses or even go public. Businesses must be managed strategically and systematically to put the benefits of good business performance. Business performance needs to be improved due to rapid environmental changes, market mechanisms that are increasingly open, competitive, and market domination. One measure of strategic orientation and business performance achievement can be seen from the overall production and marketing activities originating from MSMEs.

The purpose of this study was to analyze: (1) The effect of entrepreneurial orientation on the business performance of Micro, Small, and Medium Enterprises in West Sumatra, and (2) The effect of market orientation on the business performance of Micro, Small, and Medium Enterprises in West Sumatra.

The object of this research is focused on MSMEs in West Sumatra. The population of this study is all MSMEs in the cities of Padang, Bukittinggi, and Payakumbuh. The research sample consisted of 100 MSMEs, using proportional cluster random sampling. This type of research is causative. The analysis tool is a Structural Equation Model (SEM) using the Smart PLS version 2.0 application.
\end{abstract}

Keywords: Strategic Orientation, Business Performance.

\section{INTRODUCTION}

Competition during this disruption was getting higher, including the level of Micro, Small and Medium Enterprises (MSMEs). MSMEs With the growth of good and sustainable business performance, this provides an opportunity for MSMEs to become large businesses or even go public.

In general, MSMEs in West Sumatra are not yet unique as a competitive advantage. In several cities in West Sumatra itself, MSMEs have always experienced a significant increase every year. According to data from the West Sumatra Cooperatives and UMKM Office (2020), the total number of MSMEs in West Sumatra from 2016-2019 increased in succession, namely: 539,100 UMKM, 602,493 UMKM, 611,832 UMKM, and 621,315 UMKM.

According to Yunia (2017) [1], this phenomenon of MSME performance can be found in every province in Indonesia, especially in West Sumatra Province, whose economic base is driven by the regional superior MSME sector, especially in the field of leading industries including cracker business and the like, embroidery / embroidery business. , cakes / snacks, tempeh / tofu, furniture business, printing, and others. MSMEs have made entrepreneurship orientation an organizational culture that will be based on external basic needs, wants and market demands as the basis for strategic orientation for MSMEs. According to Imma (2014) [2], entrepreneurial orientation has a significant effect on the performance of SMEs.

Market-oriented MSMEs will follow any changes that occur in the market. According to Narver and Slater (1990) [3], market orientation is the organizational culture that's most successful in making behaviors essential to creating superior value for buyers and performance in business. Meanwhile, Lindblom (2015) [4] states that market orientation places the highest priority on staying close to the market and creating superior value for MSMEs. Furthermore, according to Kohli and Jaworski (1990) [5], market orientation may 
be a corporate culture that can lead to increased marketing performance.

\section{CONTENT AND METHOD}

\subsection{Business Performance}

According to Zimmerer and Norman (2008: 57) [6], business performance is a result of the capacity to create modern thoughts and to discover better approaches of seeing issues and openings and the capacity to apply creative solutions to problems and opportunities. to improve or to enrich people's lives. Furthermore, Agusty (2000) [7] states that business performance is one of the factors that is often used to measure the impact of the business strategy that the company has implemented. Good business performance is generated through the strategic orientation of MSMEs.

Factors that can affect business performance according to Nurdasila (2013: 10) [8] are: (1) internal environment which includes entrepreneurial orientation, ownership and access to resources, control and utilization of information technology, management systems, cultural culture, capital strength, partnerships, and business networks with parties outside the business, (2) the external environment, including those related to government policies, legal aspects, conditions of market competition, social conditions, infrastructure conditions, and how to empower infrastructure conditions, community education levels, and changes global economy. Meanwhile, according to Best (2009) [9], the achievement of marketing capabilities and performance is also supported by strong entrepreneurial orientation abilities.

\subsection{Entrepreneurial Orientation}

According to Casson (2002) [10], entrepreneurial orientation is an effort to learn about a person's values, abilities and behavior in an effort to create and innovate. Meanwhile, according to Mahmood and Hanafi (2013) [11], the entrepreneurial orientation of an entrepreneur is considered to have a significant role in the success of a business, so that the business can perform healthily. To measure entrepreneurial orientation, indicators developed from research by Brouthers, Nakos, and Dimitratos (2015) [12] are used, namely: risk-taking, innovative, proactive, competitive aggressiveness, and autonomy.

\subsection{Market Orientation}

According to Masa'deh, et al (2017) [13], market orientation provides the largest contribution to company performance compared to alternative strategic orientations, such as: innovation, learning, and entrepreneurial orientation. " Meanwhile, Lindblom (2015) [3] states that it is not market orientation that affects performance, but uses market orientation in developing marketing capabilities to improve performance. Furthermore, according to Narver and Slater (1990) [4], market orientation is a business culture in which organizations create behaviors to continue to be creative in creating superior value for customers to focus on long-term interests and profitability. Market orientation indicators adopted from Narver and Slater (1990) [3] include: (1) Customer orientation, (2) Competitive orientation, and (3) Interfunctional coordination.

\section{METHOD}

This type of research is a causal survey explanatory research. The instrument to be used is a questionnaire containing statements using a Likert scale of 1 to 5 given to respondents personally (selfadministered survey). This research was conducted in West Sumatra Province in 3 districts / cities, namely: Padang, Bukittinggi, and Payakumbuh, in 2020.

The population in this study were all of the Micro, Small and Medium Enterprises (MSMEs) in West Sumatra, totaling 621,315 units. Samples were taken using proportional cluster random sampling technique with a total of 100 people. Before distributing the questionnaire, the researcher first tested the instruments used, including validity and reliability tests

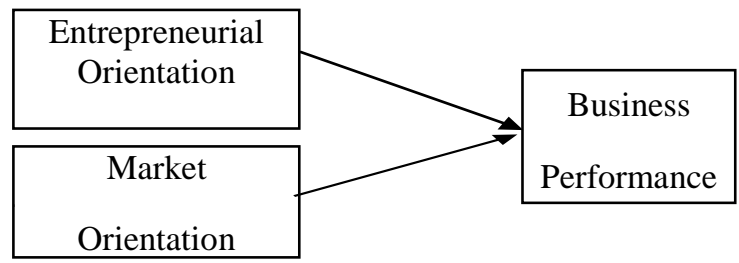

Figure 1 Research Model

\subsection{Instrument Testing}

According to Suharsimi (2010) [14], a survey is said to be substantial on the off chance that the questions on the survey are able to uncover something that will be measured by the survey. The validity of the instrument was calculated using SPSS version 24. The reliability of the constructs in this study was measured using composite reliability. Composite reliability also referred to as internal consistency is translated similar to Cronbach's Alpha.

\subsection{Data Collection and Analysis Techniques}

The data in this study, the data collection technique is done by collecting primary data which is done by using a questionnaire, using a survey technique. Data 
analysis was performed using PLS (Partial Least Square). The software used is Smart PLS version 2.0.

\section{RESULT AND DISCUSSION}

The first hypothesis in this study is that there is an influence between entrepreneurial orientation and MSME business performance in West Sumatra. Based on Table 12, the value of tcount <ttable $(0.3725$ $<1.9858)$ is obtained with a sig. 0.000 which is smaller than $\alpha=0.05$ (Sig. $0.000<0.005$ ), then Ho is rejected and $\mathrm{Ha}$ is accepted. Thus, the first hypothesis can be accepted. This means that there is an influence between entrepreneurial orientation $\left(\mathrm{X}_{1}\right)$ on MSME business performance in West Sumatra. This means that the entrepreneurial orientation obtained affects the business performance of MSMEs in West Sumatra.

The second hypothesis in this study is that there is an influence between market orientation and MSME business performance in West Sumatra. Based on Table 8 , it is obtained the value of $t$ count $<\mathrm{t}$ table $(0.5835$ $<1.9858$ ) with a sig. 0.000 which is smaller than $\alpha=$ 0.05 (Sig. $0.000<0.005$ ), then Ho is rejected and $\mathrm{Ha}$ is accepted. Thus, the second hypothesis can be accepted. This means that there is an influence between market orientation $\left(\mathrm{X}_{2}\right)$ on MSME business performance in West Sumatra. This means that the market orientation obtained affects the performance of the MSME business in West Sumatra.

\section{CONCLUSION}

There is an influence between entrepreneurial orientation and MSME business performance in West Sumatra. This means that entrepreneurial orientation affects the business performance of MSMEs in West Sumatra.

There is an influence between market orientation and MSME business performance in West Sumatra. This means that market orientation affects the performance of MSME business in West Sumatra.

\section{REFERENCES}

[1] Yunia Wardi. 2017. Orientasi Kewirausahaan pada Kinerja Usaha Kecil dan Menengah (UKM) Sumatera Barat: Analisis Peran Moderasi dari Intensitas Persaingan, Turbulensi Pasar dan Teknologi. Jurnal Manajemen Teknologi, 16 (1), 46-61.

[2] Imma Andiningtyas. 2014. Pengaruh orientasi kewirausahaan terhadap kinerja perusahaan kecil. Jurnal Manajemen Indonesia. Vol 14. No. 1. Hlm 38-46.
[3] Narver, J.C. and Slater, S.F. 1990. "The Effect of Market Orientation on Business Profitability." Jounal of Marketing, Vol 54.

[4] Lindblom, Sami Kajalo Arto. 2015. "Market orientation, entrepreneurial orientation and business performance among smallretailers." International Journal of Retail \& Distribution Management, Vol. 43 Iss 7.

[5] Kohli dan Jaworski. 2013. Market Orientation: A Measure of Market Orientation, Journal of Marketing Research XXX (Nov): Hal: 16-27.

[6] Zimmerer, Thomas W. dan Norman Scarborough. 2008. Kewirausahaan dan Manajemen Usaha Kecil. Jakarta: Salemba Empat.

[7] Agusty Ferdinand. 2000. "Manajemen Pemasaran: Sebuah Pendekatan Strategy". Research Paper Series. No. 01 Program Magister Manajemen Universitas Diponegoro (Maret).

[8] Nurdasila, D. 2013. Orientasi Kewirausahaan dan Keunggulan Bersaing Serta Kinerja Usaha Mikro.

[9] Best, R. 2009. Market Base management; Strategy for Growing Consumer Value and Profitability. New Jer-sey. Pearson Education, Inc.

[10] Casson, MC. 2002 The Entrepreneur: an Economy Theory. Oxford: Martin Robertson.

[11] Mahmmod, R. dan N. Hanafi. 2013. Entrepreneurial Orientation and Business Performance of Women-Owened Small and Medium Enterprises in Malaysia: Competitive Adavantage as A Mediator. International Journal of Business and Social Science 4 (1): 82-90.

[12] Brouthers, K.D., Nakos, G., dan Dimitratos, P. 2015. SME entrepreneurial orientation, international performance, and the moderating role of strategic alliances. Entrepreneurship Theory and Practice.

[13] Masa'deh, R., Shannak, R., Maqableh, M., \& Tarhini, A. 2017. "The Impact of Knowledge Management on Job Performance in Higher Education: The Case of The University of Jordan." Journal of Enterprise Information Management, 30(2), pp. 244-262.

[14] Suharsimi Arikunto. 2010. Prosedur Penelitian: Suatu Pendekatan Praktik. (Edisi Revisi). Jakarta: Rineka Cipta. 